\title{
Investigating the Usage of loT- Based Smart Parking Services in the Borough of Westminster
}

\author{
Guochao Peng, Sun Yat-sen University, Guangzhou, China \\ Paul David Clough, University of Sheffield, Sheffield, UK \\ Andrew Madden, A. D. Madden Academic and Editorial Consultancy Services, UK \\ Fei Xing, Sun Yat-sen University, Guangzhou, China \\ Bingqian Zhang, Sun Yat-sen University, Guangzhou, China
}

\begin{abstract}
Smart parking schemes cannot succeed without the engagement and support of the drivers who may benefit from their use. This study investigates engagement with a smart parking service in the London borough of Westminster. Factors likely to influence the use of smart parking services were identified from a literature review and incorporated into an explanatory model comprising 9 factors connected by 16 hypotheses. To test the model, residents of Westminster and visitors to the area were surveyed, resulting in a total of 212 valid responses. The responses were used to test a structural equation model using confirmatory factor analysis. The results of the analysis indicated that awareness of the scheme, perceived ease of use, perceived usefulness, cost saving, perceived privacy, and perceived security all had a direct impact on usage, with awareness being the most influential factor. The results also highlighted the fact that, despite efforts by Westminster Council to publicise the scheme, $74 \%$ of respondents had little awareness of it, suggesting the need for improved publicity.
\end{abstract}

\section{KEYWORDS}

Internet of Things, Smart City, Smart Parking, Usage, User Perception

\section{INTRODUCTION}

Despite its many advantages, continuous urbanisation has brought a wide range of problems, many of which are associated with rapid growth in car use. According to the Texas A\&M Transportation Institute for example, in 2011 people living in US cities endured 5.5 billion hours of traffic delay, resulting in the use of an additional 2.9 billion gallons of fuel costing approximately $\$ 121$ billion and causing the emission of 56 billion lbs of $\mathrm{CO}_{2}$ (Schrank et al, 2012). These figures are approximately five times higher than corresponding statistics from 1982. Such problems are not limited to the USA; in 2012, a report by Christidis and Rivas estimated the annual cost of traffic congestion in the EU to be around $€ 111$ billion (approximately $1 \%$ of the EU's total GDP). 
The problems associated with congestion do not just affect other drivers. Users of public transport are subject to the delays caused by traffic jams; and cyclists, pedestrians and residents are all affected by noise and pollution (Department for Business, Innovation and Skills, 2013).

One significant factor that contributes to congestion is limited parking. For example, in an analysis of data gathered from studies of cities around the world between 1927 and 2001, Shoup (2006) found that most of the studies reported that drivers searching for a parking space spent over 6 minutes 'cruising'. Inexperienced drivers and visitors to a city are likely to take even longer (Teodorović \& Lučić, 2006), with drivers surveyed in Frankfurt in 1992 reporting cruising times of over an hour (Axhausen et al, 1994). Such is the negative impact of seeking for free parking spaces that, in some cities, a driver doing so is referred to as a "traffic-parasite" (Giuffrè \& Siniscalchi, 2012).

In many city centres, land is at a premium, so increasing the number of available parking spaces is not always an option. Smart Parking opens up possibilities for the better management of existing parking, allowing spaces to be found more quickly and filled more effectively. However, although many technologies can contribute to such schemes, they cannot succeed without the engagement of the drivers who may benefit from them.

This paper explores which factors have an impact on the engagement of drivers with Smart Parking services, and which may affect the use of on-street parking. To do so, it draws on the experiences of users of an innovative Smart Parking initiative that was introduced by the London Borough of Westminster in 2014. The research reported on here seeks to increase understanding of how new technologies associated with a Smart Parking scheme are perceived; and to explore and analyse factors that might influence the use of such a scheme. To do so, it draws on both technology acceptance theories and social influence theories to incorporate influencing factors into a predictive exploratory model.

The remainder of the paper is structured as follows. Section 2 provides a review of relevant existing literature on Smart Cities and Smart Parking; Section 3 describes our proposed theoretical explanatory model; this is followed by Section 4 that describes the research methodology, including data collection and analysis. The results of the study are presented in Section 5, including confirmation of the explanatory model and Section 6 discusses these in light of the existing literature. Finally, Section 7 concludes the paper.

\section{LITERATURE REVIEW}

\subsection{Smart Cities}

"Smart cities" have been defined in a variety of ways by different authors (e.g. Allwinkle \& Cruickshank, 2011; Nam \& Pardo, 2011; Chourabi et al, 2012, Peng, Nunes \& Zheng, 2017). What links the definitions though, is a focus on the possibilities raised by the ability to connect a growing range of technologies (e.g. sensors, Internet of Things, cloud computing, big data analytics, and mobile devices). As a result, Smart City literature tends to emphasise the technical and engineering dimensions, such as IoT architecture and wireless sensor networks (Gope \& Hwang, 2015; Minoli et al., 2017), Smart City testbeds and prototype design (Cardone et al, 2014), simulation models (Yamagata \& Seya, 2013), and big data analytic tools and algorithms (Qiu et al, 2017).

However, the success of Smart Cities does not rely solely on technological factors: consideration of the city's population and of decisions relating to its well-being, is essential. Data generated, processed and analysed by Smart City technologies should be used to inform decisions relevant to the running of a city. The shared data is both localised and up-to-date, and has the potential to improve decisionmaking relevant to transport, healthcare, and education, leading to a better quality of life for citizens of the smart city through enhancement of key infrastructures, utilities and services (Peng \& Nunes, 2017, Neirotti et al, 2014; Nam \& Pardo, 2011, Bélissent, 2010). Therefore, there is an increasingly recognition of the need for researchers to explore the diverse socio-technical issues that may affect 
Smart City development. Such issues include citizen perceptions and concerns about data privacy and security (Belanche-Gracia et al, 2015), the role of big data, data management and open data (Hashem et al, 2016; Pereira et al, 2017), and factors influencing engagement with smart applications and services (Yeh, 2017; Dehghani et al, 2018; Sepasgozar et al, 2019). However, most of these studies focused on Smart Cities as a whole, rather than focusing on a particular domain or application. One under-researched area, in which there have already been significant developments, is Smart Parking.

\subsection{Smart Parking}

By making transport more efficient Smart Parking can help to reduce congestion and noise; thereby making cities cleaner, quieter, cheaper, and more effective. As a result, systems which use advanced technologies to help motorists locate, reserve, and pay for parking have been implemented in many European, American, and Japanese cities (Rodier \& Shaheen, 2010).

Smart Parking schemes match the requirements of drivers to the availability and location of parking spaces in real-time. They therefore need to use technologies capable of showing the position of parking places relative to the driver's position and recognise the current status of a space: available or unavailable. Parking Guidance and Information systems (PGI systems) have been popular since the 1980s (e.g. Polak, Hilton, Axhausen \& Young, 1990; Axhausen et al, 1994), and typically consist of the following:

- $\quad$ Roadside Variable Message Signs (VMS) capable of displaying a limited set of pre-defined (and variable) messages;

- A counting mechanism to record the number of cars entering and leaving car parks;

- A control centre that can process data on car park occupancy and control the display of information on the VMS;

- A telecommunications network that facilitates exchanges of information between car park, control centre and VMS (Polak et al, 1990).

Such schemes, however, have inherent disadvantages. Information on VMSs can only be seen by drivers already in traffic who are approaching their destinations where the VMSs are physically installed (Teodorović \& Lučić, 2006). Therefore, instead of searching speculatively for parking spaces which may be available, in many occasions, drivers who receive the same information compete for spaces which were available at the time of the last update (Geng \& Cassandras, 2012). More importantly, PGI systems are only of use for finding off-street parking (e.g. car garages with relatively simple parking conditions). PGIs however are not suitable for on-street parking spaces, which are associated with more complicated road environment and higher crash risks (Edquist et al., 2012). This is a significant issue since research suggests that in many places, on-street parking spots are in far higher demand than other forms of parking. For example, Marshall, Garrick and Hansen (2008) found that demand for on-street parking spaces in six U.S. towns had an average non-peak occupancy of $81.6 \%$ and a peak occupancy of $94.5 \%$, making them considerably more popular than either off-street parking or multi-storey car parks.

The need to make on-street parking smarter is being addressed by a new generation of Smart Parking solutions, which have emerged more recently in the $21^{\text {st }}$ Century. Wireless sensors beneath each parking space on a street relay information about the status of that parking space to drivers who use a smart phone app to navigate to available parking (Pierce \& Shoup, 2013; Mingardo, van Wee \& Rye, 2015). Such apps can draw on technology built into a smart phone, such as GPS and electronic payment services, to navigate drivers to an available space and for payment of parking fees.

Until recently, Smart Parking systems sought to increase efficiency by allowing drivers to make choices based on up-to-date information. Increasingly, however, systems seek to optimise allocation of parking spaces by delegating the choice of parking place to some form of algorithmic approach, which assigns spaces according to pre-established criteria. For example, Geng \& Cassandras (2012) 
describe a system which takes into consideration cost of parking and the walking distance between the parking place and the driver's final destination.

However, like all information systems, Smart Parking schemes need to be considered within the context of the social and economic environment into which the technology is applied (Rodier \& Shaheen, 2010; Peng et al, 2017). Such factors can have a considerable influence on the success of Smart Parking systems and on the nature of its impact. Pricing strategies, and policies that affect the availability of parking throughout the day, have been used to change driver behaviour in ways that discourage drivers from parking at busy times and encourage commuters to make greater use of public transport (Teodorović and Lučić, 2006, Giuffrè and Siniscalchi, 2012). Such initiatives can contribute to a reduction in congestion, and the tools associated with Smart Parking can help to implement them.

In general, there is a very rich amount of research focusing on technology adoption and usage, such as e-commerce (Huy et al., 2012), social media (Rouibah and Hamdym 2009; Oghuma et al., 2016), online banking (Khan et al., 2017), e-services (Xu et al., 2013), mobile government (Talukder et al., 2020), and even smart technologies (Shin et al., 2018, Zhang et al., 2021). In the context of Smart Parking, some attempts have been made to identify and analyse user behaviors associated with the usage of such technology, for example the work by Rodier \& Shaheen (2010) who surveyed users of a Smart Parking project designed to promote use of the Bay Area Rapid Transport system in California and gained insights into user patterns (e.g. usage frequency and travel effects) of the project. However, on the whole it is rare to find studies looked into factors affecting the usage of Smart Parking schemes. In this paper we further research on the effect of sociological factors by considering user engagement with a Smart Parking scheme in London. Data collected from the general public regarding their use of on-street parking facilities is analysed to determine the most influential factors.

\section{ESTABLISHING THE THEORETICAL MODEL}

\subsection{Theoretical models and user acceptance}

In recent years there has been considerable research into factors which affect the acceptance of new information technologies. Several models have been introduced which consider different aspects of user acceptance, such as Technology Acceptance Model or TAM (Davis, 1985), the Unified Theory of Acceptance and Use of Technology or UTAUT (Venkatesh et al, 2003), Theory of Planned Behavior or TPB (Ajzen, 1991), and Innovation Diffusion Theory or IDT (Roger, 1995). In general, however, the models seek to address two key questions:

1. Do peoples' perceptions of a new technology influence its use?

2. What factors influence the use of a new technology?

The proposed model developed in this article (Figure 1) addresses the same questions, but with a focus on specific aspects relevant to Smart Parking.

\subsection{Do Peoples' Perceptions of a New Technology Influence its Use?}

Perceived Ease of Use (PEoU) and Perceived Usefulness (PU) were two of the factors in the Technology Acceptance Model (TAM) and are defined as (respectively) "the degree to which an individual believes that using a particular system would be free of physical and mental effort" and "the degree to which an individual believes that using a particular system would enhance his or her job performance" (Davis, 1985). Both factors have been widely incorporated in models exploring the acceptance of technologies used in Smart Cities and Smart Parking schemes (Kianpisheh et al, 2011; Aylin et al, 2017; Sepasgozar et al, 2019). The possible impact of PEoU and PU on usage of Smart Parking is explored in $\mathrm{H} 1$ and $\mathrm{H} 2$, respectively. 
H1: Perceived Ease of Use affects the use of the parking scheme (H5)

H2: Perceived Usefulness affects the use of London's Smart Parking scheme (H7)

\subsection{What Other Factors Influence the Use of a New Technology?}

One factor that has long been recognised as affecting the adoption of new technologies in general, arises from the experiences and opinions of people important to the potential user (Davis, 1985). Social influence (SI) is incorporated into a number of widely used models of technology acceptance, including TAM and the Unified Theory of Acceptance and Use of Technology (UTAUT) (Venkatesh et al, 2003). In the proposed model the possible impact on usage of Smart Parking was explored in $\mathrm{H} 3$. The possibility that SI affects PU is explored in H4.

H3: Social Influence affects the use of London's Smart Parking scheme (H10)

H4: Perceived Usefulness is affected by Social Influence (H13)

Of specific relevance to Smart Parking is the potential contribution that associated technologies can make to Cost Saving (CS). Studies have shown that parking costs affect driver behaviour (Teodorović \& Lučić, 2006). However, better-organised and more flexible parking has the potential to reduce costs indirectly through reduced fuel consumption (Shoup, 2005; Rodier \& Shaheen, 2010; Fabusuyi, Hampshire \& Hill, 2013; Lan \& Shih, 2014, Peng, Nunes \& Zheng, 2017). The possibility that CS plays a part in motivating the use of Smart Parking and PU is considered in H5 and H6, respectively.

H5: Potential Cost Savings affect the use of London's Smart Parking scheme (H8)

H6: Perceived Usefulness is affected by potential Cost Savings (H11)

Privacy and security have long been issues of concern affecting the use of new technologies. Where financial transactions, such as payment for parking, are involved (Rodier \& Shaheen, 2010) reasons for such concerns are obvious; but additional risks also exist. Security of information is a concern because of some of the new protocols being developed for online services in mobile environments, such as cars seeking parking spaces. Vehicular Ad hoc NETworks (VANETs) provide a key role in Intelligent Transport Networks and technical issues or malicious activity, such as Denial of Service attacks, could impair the decision-making of motorists and adversely affect traffic flow (Di Maio et $a l, 2016)$. Information security also relates to issues of privacy: data could be used to infer movements and routines, creating possible threats to driver safety and privacy. As a result of such concerns, perceived privacy and perceived security have been widely incorporated into models exploring the acceptance of Smart Cities and Smart Parking schemes. For example, Sepasgozar et al (2018) included all three factors in their Urban Services Technology Acceptance Model (USTAM) and both factors are included in our new proposed model. $\mathrm{H} 7$ and $\mathrm{H} 8$ are explored to determine whether perceived privacy and perceived security have a direct impact on the use of Smart Parking. We also consider whether peoples' perceptions of security may affect their perceptions of privacy (H9).

H7: Perceived Privacy affects the use of London's Smart Parking scheme (H14)

H8: Perceived Security affects the use of London's Smart Parking scheme (H15)

H9: Perceived Security affects Perceived Privacy (H16)

For a Smart Parking scheme to be useful information must not only be secure; it must also be accurate. New technologies are being used increasingly to ensure that information is up-to-date (e.g., Maria et al, 2016). However, unless the existence and merits of such a scheme are effectively 


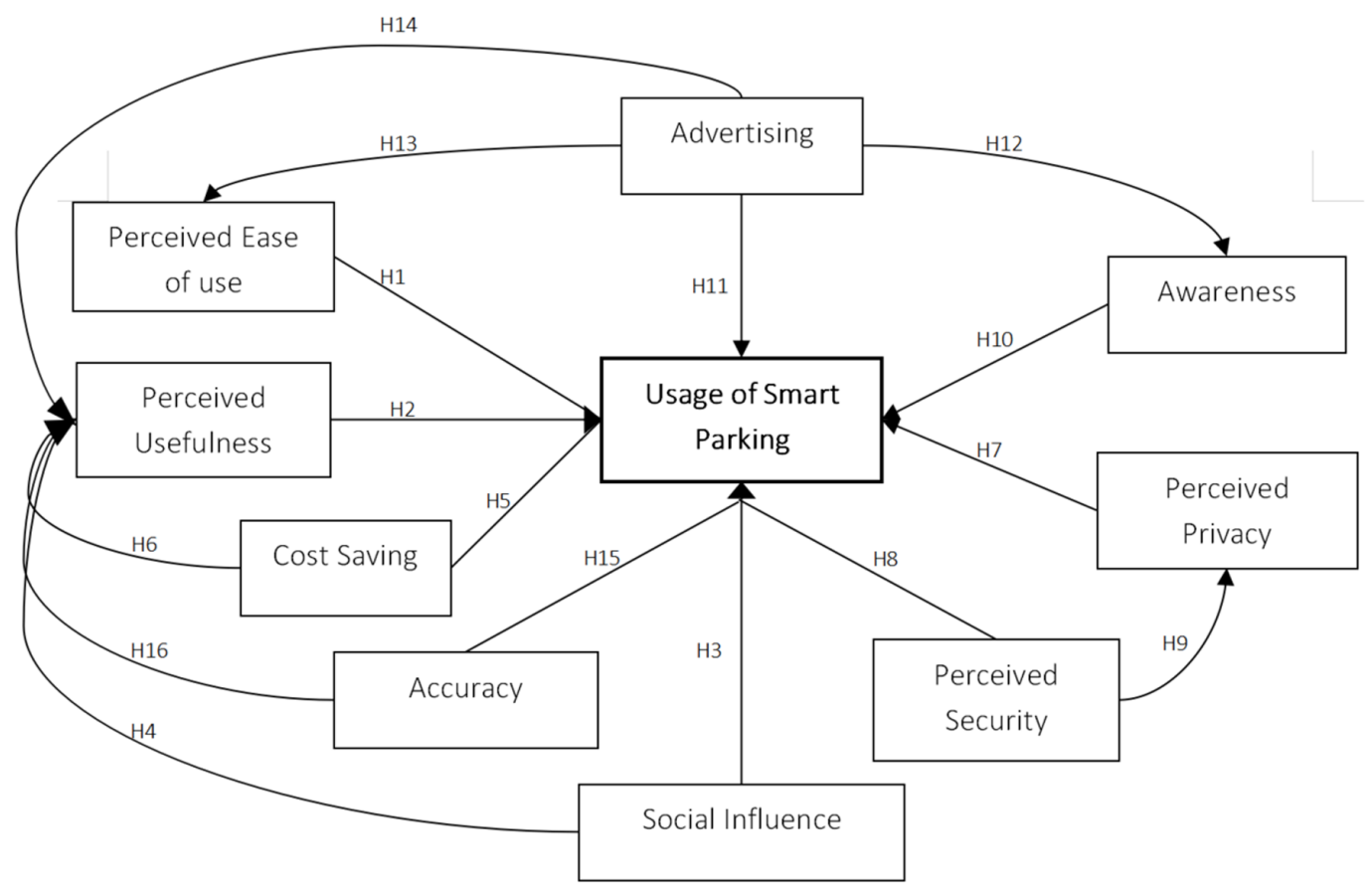

publicised, the scheme is likely to be under-used (Peng, Nunes \& Zheng, 2017). The possible impact of Accuracy, Advertising and Awareness on usage of Smart Parking is assessed in H10-H16.

H10: Use of London's Smart Parking scheme is affected by awareness of the scheme (H1)

H11: Use of the scheme is affected by the advertising of it $(\mathrm{H} 2)$

H12: Awareness of the scheme is affected by the advertising of it $(\mathrm{H} 3)$

H13: Perceived Ease of Use is affected by the advertising of the scheme (H4)

H14: Perceived Usefulness is affected by advertising of the scheme (H6)

H15: Accuracy of the ParkRight App affects the use of London's Smart Parking scheme (H9)

H16: Perceived Usefulness is affected by the Accuracy of the ParkRight App (H12)

\subsection{The Proposed Model}

The factors discussed above are incorporated into the proposed theoretical model, which comprises ten factors connected by sixteen hypotheses.

\section{RESEARCH METHODOLOGY}

\subsection{ParkRight: London's On-Street Smart Parking Service}

According to the UK's Department for Transport (2018) in 2017 there were nearly 2.8 million cars and light goods vehicles registered in London, making it one of the most congested cities in the UK. A particularly congested region is the City of Westminster: in 2017, it had an average of 24 cars and light goods vehicles registered per hectare (Greater London Authority, n.d.). Westminster is also subject to considerable traffic from other parts of London: it is the location of the UK's parliament, home to the headquarters of many UK Government departments, and contains numerous tourist 
attractions and popular shopping areas. To address some of the problems arising from the resulting congestion, Westminster City Council have invested almost £890,000 (\$1.4million) to implement a Smart Parking system (Curtis, 2014). In a pilot project, 189 sensors were installed in on-street parking spaces in five streets. The pilot was successful enough to justify the expansion of the system to 3,000 sensors by 2014 (Collins, 2014).

The scheme uses three technologies to collect, analyse, and disseminate real-time information regarding the availability of parking spaces. Wireless sensors detect whether or not parking bays are occupied. This data is relayed to a parking management tool, which then updates a mobile app ('ParkRight') capable of directing drivers to available parking spaces (Telegraph, 2014).

This is the first and largest project of its kind in the UK and had been in use for a number of years by the time of this research. As has been noted, the City of Westminster is home to numerous tourist attractions, leading to a lot of leisure traffic. More importantly however, Westminster also houses the UK parliament and many government offices, which generate a considerable amount of commuter traffic. Commuters have substantially less flexibility than tourists in the choice of when and where to park, which increases pressure on the limited parking spaces. In such an environment, people are likely to be motivated to use a resource (such as a Smart Parking scheme) that would make parking easier. This makes the City of Westminster a highly suitable context to carry out an empirical study into sociological factors impacting user engagement of Smart Parking technologies.

\subsection{Questionnaire Survey}

Questionnaire-based surveys are an efficient and economical way to collect large samples of data from across a wide area over a short period of time (Peng \& Annansingh 2013; Bryman 2004: 133-134). For this study, a questionnaire was developed to assess the influence of the factors shown in Figure 1 on the smart parking scheme in London. The questionnaire was designed in two parts: Part 1 gathered demographic information, such as age, gender and education; Part 2 used 5-point Likert-scale items ranging from 'strongly disagree' to 'strongly agree' to investigate the factors listed in Figure 1 . The actual constructs/factors and items designed in the survey, together with definitions and sources are presented in Table 2. Each construct has 3 associated items, one of which (given in italics in Table 1) was purposely phrased to reflect the opposite opinion of the other two in order to make respondents think more carefully when filling in the survey and so increase the quality of their responses. Moreover, the questionnaire was subject to a pilot test involving $15 \mathrm{MSc}$ and $\mathrm{PhD}$ students in the researchers' own institution. Based on the responses to this study, the questionnaire was improved by rewording five of the items and removing typographical errors.

\subsection{Sampling and Data Collection}

The research team collected data from drivers who regularly visited the West End of London, where the Smart Parking service operates. This was based on the assumption that these drivers were more likely to be users of the Smart Parking service than visitors to London, or London residents who worked in other parts of the city.

In order to better explain the study to target respondents as well as to enhance data quality and response rate, the research team made an effort to carry out the questionnaire in person (rather than in conventional online form). As such, data was collected by researchers who visited different onstreet parking areas in the West End of London. They approached drivers who had parked the car in the area, explained the project, and invited the drivers to complete the questionnaire. If a driver did not have time, or was unwilling to complete the questionnaire on the street, the researchers referred them to an electronic version available on Google Forms. The sampling method is therefore a nonprobability sample. A total of 1,044 drivers were approached in this way and 212 completed the survey in full, representing a response rate of $20.3 \%$. Amongst the respondents, 179 drivers filled in the questionnaire immediately; 33 completed the online survey later. The demographic profile of respondents is given in Table 2 and the results and findings from this study are presented below. 


\section{Table 1. Questionnaire constructs and sources}

\begin{tabular}{|c|c|c|c|}
\hline Construct & Definition & Items & Sources \\
\hline \multirow[t]{3}{*}{ Awareness (AW) } & \multirow{3}{*}{$\begin{array}{l}\text { The extent to which citizens are } \\
\text { aware of Smart Parking and its } \\
\text { benefits. }\end{array}$} & $\begin{array}{l}\text { AW1: I often hear about the smart car parking service in West } \\
\text { End; }\end{array}$ & \multirow[t]{3}{*}{$\begin{array}{l}\text { Peng, Nunes \& Zheng, } \\
\text { (2017) }\end{array}$} \\
\hline & & AW2: I know the benefits that I can get from the ParkRight app; & \\
\hline & & AW3: I am not sure why the smart parking service is needed. & \\
\hline \multirow[t]{3}{*}{ Accuracy (AC) } & \multirow{3}{*}{$\begin{array}{l}\text { The extent to which information } \\
\text { provided by Smart Parking } \\
\text { services is accurate and reliable. }\end{array}$} & $\begin{array}{l}\mathrm{AC} 1 \text { : Information provided by the smart parking service is } \\
\text { accurate; }\end{array}$ & \multirow[t]{3}{*}{ Maria et al (2016) } \\
\hline & & $\begin{array}{l}\text { AC2: I feel information shown in the ParkRight app has high } \\
\text { level of accuracy; }\end{array}$ & \\
\hline & & $\begin{array}{l}\text { AC3: I receive misleading and inaccurate parking information } \\
\text { from the smart parking app. }\end{array}$ & \\
\hline \multirow[t]{2}{*}{ Advertising (AD) } & \multirow{2}{*}{$\begin{array}{l}\text { The extent to which the provider } \\
\text { has promoted the Smart Parking } \\
\text { service to potential users. }\end{array}$} & $\begin{array}{l}\text { AD2: The advertisement about smart car parking can always be } \\
\text { seen around the city; }\end{array}$ & \multirow[t]{2}{*}{$\begin{array}{l}\text { Peng, Nunes \& Zheng, } \\
\text { (2017) }\end{array}$} \\
\hline & & $\begin{array}{l}\text { AD3: I feel the provider is not advertising the smart car parking } \\
\text { service enough. }\end{array}$ & \\
\hline \multirow{2}{*}{$\begin{array}{l}\text { Perceived Ease of } \\
\text { Use (PEOU) }\end{array}$} & \multirow{2}{*}{$\begin{array}{l}\text { The extent to which the service is } \\
\text { perceived to be easy to use. }\end{array}$} & PEOU1: I think the London smart parking app is easy to use; & \multirow[t]{2}{*}{ Davis et al (1989) } \\
\hline & & $\begin{array}{l}\text { PEOU2: I can use the smart parking service without requiring } \\
\text { any additional support. }\end{array}$ & \\
\hline \multirow[t]{3}{*}{ Social Influence (SI) } & \multirow{3}{*}{$\begin{array}{l}\text { The extent to which citizens' } \\
\text { opinions of Smart Parking } \\
\text { are affected by the people } \\
\text { surrounding them }\end{array}$} & $\begin{array}{l}\text { SI1: People that I know feel positive about the smart parking } \\
\text { service; }\end{array}$ & \multirow[t]{3}{*}{ Venkatesh et al (2000) } \\
\hline & & $\begin{array}{l}\text { SI2: When I talk to people about smart parking, they usually give } \\
\text { good comments about it; }\end{array}$ & \\
\hline & & SI3: People around me don't like using the smart parking service. & \\
\hline \multirow{2}{*}{$\begin{array}{l}\text { Perceived Usefulness } \\
\text { (PU) }\end{array}$} & \multirow{2}{*}{$\begin{array}{l}\text { The extent to which the Smart } \\
\text { Parking service is considered to } \\
\text { be useful }\end{array}$} & PU2: I think the smart parking service is useful and effective; & \multirow[t]{2}{*}{ Davis et al (1989) } \\
\hline & & PU3: This smart parking service is useless and not doing its job. & \\
\hline \multirow{3}{*}{$\begin{array}{l}\text { Perceived Security } \\
\text { (PS) }\end{array}$} & \multirow{3}{*}{$\begin{array}{l}\text { The extent to which citizens } \\
\text { perceive that their data in the } \\
\text { Smart Parking app is securely } \\
\text { protected }\end{array}$} & PS1: The smart parking app has high level of data security; & \multirow[t]{3}{*}{$\operatorname{Lin} \& \mathrm{Lu}(2015)$} \\
\hline & & $\begin{array}{l}\text { PS2: I think that data in the smart parking service is securely } \\
\text { protected; }\end{array}$ & \\
\hline & & $\begin{array}{l}\text { PS3: I don't think it is secure to use the smart parking app to } \\
\text { search and pay for parking spaces. }\end{array}$ & \\
\hline \multirow[t]{3}{*}{$\begin{array}{l}\text { Perceived Privacy } \\
\text { (PP) }\end{array}$} & \multirow[t]{3}{*}{$\begin{array}{l}\text { The extent to which citizens } \\
\text { perceive that their personal data in } \\
\text { the Smart Parking app is treated } \\
\text { as confidential }\end{array}$} & $\begin{array}{l}\text { PP1: I think my data stored in the smart parking app will be } \\
\text { treated as confidential and will not be accessed by unauthorised } \\
\text { parties; }\end{array}$ & \multirow[t]{3}{*}{ Sepasgozar et al (2019) } \\
\hline & & PP2: I trust the smart parking system's data privacy policy; & \\
\hline & & $\begin{array}{l}\text { PP3: Using the smart parking app has a high level of data } \\
\text { privacy risk. }\end{array}$ & \\
\hline \multirow[t]{3}{*}{ Cost Saving (CS) } & \multirow[t]{3}{*}{$\begin{array}{l}\text { The extent to which the service } \\
\text { can reduce citizens' parking costs }\end{array}$} & $\begin{array}{l}\text { CS1: The smart parking service can lead to petrol and cost } \\
\text { saving; }\end{array}$ & \multirow[t]{3}{*}{ Teodorović \& Lučić (2006) } \\
\hline & & $\begin{array}{l}\text { CS2: The service can help me to reduce parking searching time } \\
\text { and petrol usage; }\end{array}$ & \\
\hline & & $\begin{array}{l}\text { CS3: I don't think it saves my petrol usage with the smart } \\
\text { parking service. }\end{array}$ & \\
\hline Usage (US) & $\begin{array}{l}\text { Frequency of use of the Smart } \\
\text { Parking service. }\end{array}$ & $\begin{array}{l}\text { US1: I often use London's smart parking service; } \\
\text { US2: I use the ParkRight app on a regular basis; } \\
\text { US3: I don't usually use this app when searching for parking } \\
\text { space }\end{array}$ & Davis et al (1989) \\
\hline
\end{tabular}


Table 2. Demographics of the collected data $(N=212)$

\begin{tabular}{|c|c|c|c|}
\hline Measure & Response & Frequency & $\%$ \\
\hline \multirow[t]{2}{*}{ Gender } & Male & 120 & 56.6 \\
\hline & Female & 92 & 43.4 \\
\hline \multirow[t]{5}{*}{ Age } & $18-24$ & 54 & 25.5 \\
\hline & $25-34$ & 52 & 24.5 \\
\hline & $35-44$ & 60 & 28.3 \\
\hline & $45-59$ & 34 & 16.0 \\
\hline & 60 or above & 12 & 5.7 \\
\hline \multirow[t]{5}{*}{ Education level } & Less than high school & 12 & 5.7 \\
\hline & High school diploma & 58 & 27.3 \\
\hline & Bachelor degree & 90 & 42.5 \\
\hline & Master degree & 41 & 19.3 \\
\hline & PhD degree & 11 & 5.2 \\
\hline \multirow[t]{5}{*}{ Monthly income } & $£ 1,499$ or less & 62 & 29.2 \\
\hline & $£ 1,500-£ 2,499$ & 50 & 23.6 \\
\hline & $£ 2,500-£ 3,499$ & 50 & 23.6 \\
\hline & $£ 3,500-£ 4,499$ & 36 & 17.0 \\
\hline & $£ 4,500$ or more & 14 & 6.6 \\
\hline \multirow[t]{2}{*}{ Connection with London } & Live or work there & 187 & 88 \\
\hline & Just visiting & 25 & 12 \\
\hline
\end{tabular}

\section{DATA ANALYSIS AND RESULTS}

The data was analysed using SPSS plus AMOS 20. Results and findings are presented and discussed below.

\subsection{Confirmatory Factor Analysis and Reliability Tests}

To confirm that the collected data has sufficient reliability and validity, a Confirmatory Factor Analysis (CFA) on the measurement model was performed. The results of the CFA (Table 4) resulted in four items being removed from the analysis: one item respectively from PEOU, AD, PU and US. These items lack reliability (with a factor loading score below 0.5 ) and by removing them the researchers were able to suggest a better measurement scale (Lewis-Beck, 1994; Mojtahed et al, 2014). The reliability of the data was assessed using Cronbach's alpha. Opinions differ about what value of Cronbach's alpha is acceptable. Researchers, such as Davis (1964) and Nunnally (1978) have suggested that acceptable values are between 0.5 and 0.6 for new scales. A stricter acceptance value of 0.7 was proposed by Kaplan \& Saccuzzo (2008) and Nunnally \& Bernstein (1967).

As shown in Table 3, the results of Cronbach's alpha test for all variables exceeded the lower acceptance values, and one (Advertising) narrowly fell short of the higher acceptance value. Therefore, the collected data was considered to be internally reliable. Furthermore, convergent validity was measured by Composite Reliability (CR) and Average Variance Extracted (AVE). The CR values shown in Table 3 were all above 0.82 (higher than the acceptable value of 0.7), and AVEs were all higher than the suggested acceptable value of 0.5 (Lin \& Lu, 2015). These results indicate good convergent validity of the measurement scales. To determine discriminant validity, the shared variances between 
Table 3. Descriptive statistics and convergent validity

\begin{tabular}{|c|c|c|c|c|c|c|c|}
\hline Constructs & Items & $\begin{array}{c}\text { Factor } \\
\text { loadings }\end{array}$ & Mean & SD & $\begin{array}{c}\text { Cronbach's } \\
\text { alpha }\end{array}$ & CR & AVE \\
\hline \multirow[t]{3}{*}{ Awareness (AW) } & AW1 & 0.783 & 2.48 & 1.21 & 0.864 & 0.88 & 0.62 \\
\hline & AW2 & 0.852 & & & & & \\
\hline & AW3 & 0.801 & & & & & \\
\hline \multirow[t]{3}{*}{ Accuracy (AC) } & $\mathrm{AC} 1$ & 0.893 & 3.13 & 1.33 & 0.853 & 0.85 & 0.71 \\
\hline & $\mathrm{AC} 2$ & 0.862 & & & & & \\
\hline & AC3 & 0.870 & & & & & \\
\hline \multirow[t]{2}{*}{ Advertising (AD) } & AD2 & 0.880 & 3.16 & 1.26 & 0.686 & 0.91 & 0.65 \\
\hline & AD3 & 0.848 & & & & & \\
\hline \multirow{2}{*}{$\begin{array}{l}\text { Perceived Ease of } \\
\text { Use (PEOU) }\end{array}$} & PEOU1 & 0.847 & 3.43 & 1.35 & 0.769 & 0.86 & 0.73 \\
\hline & PEOU2 & 0.889 & & & & & \\
\hline \multirow[t]{3}{*}{ Social Influence (SI) } & SI1 & 0.801 & 3.71 & 1.07 & 0.788 & 0.89 & 0.78 \\
\hline & SI2 & 0.891 & & & & & \\
\hline & SI3 & 0.809 & & & & & \\
\hline \multirow{2}{*}{$\begin{array}{l}\text { Perceived Usefulness } \\
\text { (PU) }\end{array}$} & PU2 & 0.836 & 4.12 & 1.28 & 0.744 & 0.90 & 0.84 \\
\hline & PU3 & 0.911 & & & & & \\
\hline \multirow{3}{*}{$\begin{array}{l}\text { Perceived Security } \\
\text { (PS) }\end{array}$} & PS1 & 0.838 & 3.76 & 1.35 & 0.823 & 0.87 & 0.61 \\
\hline & PS2 & 0.884 & & & & & \\
\hline & PS3 & 0.760 & & & & & \\
\hline \multirow{3}{*}{$\begin{array}{l}\text { Perceived Privacy } \\
\text { (PP) }\end{array}$} & PP1 & 0.854 & 3.35 & 1.21 & 0.854 & 0.82 & 0.67 \\
\hline & PP2 & 0.864 & & & & & \\
\hline & PP3 & 0.836 & & & & & \\
\hline \multirow[t]{2}{*}{ Cost Saving (CS) } & CS1 & 0.844 & 3.41 & 1.04 & 0.811 & 0.85 & 0.76 \\
\hline & $\begin{array}{l}\mathrm{CS} 2 \\
\mathrm{CS} 3\end{array}$ & $\begin{array}{l}0.782 \\
0.897\end{array}$ & & & & & \\
\hline \multirow[t]{2}{*}{ Usage (US) } & US1 & 0.896 & 3.74 & 1.18 & 0.895 & 0.93 & 0.82 \\
\hline & US2 & 0.859 & & & & & \\
\hline
\end{tabular}

constructs were compared with the AVEs for individual constructs. Table 4 shows that the AVEs were all higher than the shared variances. The measurement scales thus have good discriminant validity (Fornell \& Larcker, 1981).

To ensure that the factors in our model were not correlated (i.e., non-significant multicollinearity), the Variance-Inflation Factor (VIF) and tolerance were calculated. The results showed that the tolerance indicators for all the factors in the model are greater than 0.1 , with corresponding VIF values being below 10. These values conform to the common cut-off threshold (Hair et al, 1998), indicating that multicollinearity is not a concern.

Prior to testing the hypotheses, the researchers also assessed the overall Goodness-of-fit of the measurement model using six common measures: $\chi^{2} / \mathrm{df}$, Goodness of Fit Index (GFI), Adjusted Goodness of Fit Index (AGFI), Normed Fit Index (NFI), Comparative Fit Index (CFI), and Root Mean Square Error of Approximation (RMSEA). Results for goodness-of-fit were as follows: $\chi^{2} / \mathrm{df}=2.16$, 
Table 4. Discriminant validity

\begin{tabular}{|c|c|c|c|c|c|c|c|c|c|c|}
\hline Construct & AW & AC & AD & PEOU & SI & PU & PS & PP & CS & US \\
\hline AW & 0.71 & & & & & & & & & \\
\hline $\mathrm{AC}$ & 0.21 & 0.76 & & & & & & & & \\
\hline $\mathrm{AD}$ & 0.26 & -0.11 & 0.78 & & & & & & & \\
\hline PEOU & 0.14 & 0.26 & 0.21 & 0.89 & & & & & & \\
\hline SI & 0.35 & 0.15 & 0.32 & -0.11 & 0.85 & & & & & \\
\hline PU & -0.21 & 0.23 & 0.18 & 0.23 & 0.31 & 0.85 & & & & \\
\hline PS & -0.11 & -0.06 & 0.35 & 0.09 & -0.13 & 0.32 & 0.74 & & & \\
\hline PP & 0.23 & 0.23 & 0.12 & 0.36 & 0.41 & 0.11 & 0.16 & 0.86 & & \\
\hline $\mathrm{CS}$ & 0.41 & 0.13 & 0.03 & 0.13 & 0.22 & 0.28 & -0.08 & 0.37 & 0.74 & \\
\hline US & 0.22 & -0.06 & 0.36 & 0.27 & 0.18 & 0.43 & 0.39 & 0.29 & 0.36 & 0.73 \\
\hline
\end{tabular}

Note: Off-diagonals are shared variances; diagonals (italic) are square roots of AVEs; for discriminant validity, diagonals should be higher than offdiagonals.

$\mathrm{GFI}=0.919, \mathrm{AGFI}=0.84, \mathrm{NFI}=0.80, \mathrm{CFI}=0.905$, and RMSEA $=0.053$ (see Table 5). All indices exceeded the recommended values (e.g., Lin \& Lu, 2015; Mojtahed et al, 2014; Scott, 1994; Hair et al, 1998; Bagozzi \& Yi, 1988), indicating that the measurement model achieved an adequate fit.

Overall, the range of test results confirmed that the questionnaire was adequate for the purpose of collecting reliable and valid data and could be used to test the hypotheses listed above.

\subsection{Testing the Structural Model}

\subsubsection{Hypothesis Testing}

The structural model and hypotheses associated with the defined factors were tested using AMOS 22.0. As shown in Table 5, the structural model also has an adequate model fit $\left(\chi^{2} / \mathrm{df}=2.13\right.$, GFI $=0.912$, $\mathrm{AGFI}=0.832, \mathrm{NFI}=0.822, \mathrm{CFI}=0.914, \mathrm{RMSEA}=0.051)$. Results of the hypotheses analysis are shown in Table 6 and indicate that usage of London's Smart Parking service is significantly affected by Awareness $(\beta=0.765, p<0.001)$, Perceived Ease of Use $(\beta=0.328, p<0.001)$, Perceived Usefulness

Table 5. Goodness-of-fit measures for the structural model

\begin{tabular}{|l|l|l|l|}
\hline \multicolumn{1}{|c|}{ Statistics } & \multicolumn{1}{|c|}{ Recommended values } & \multicolumn{1}{c|}{$\begin{array}{c}\text { Measurement } \\
\text { model }\end{array}$} & \multicolumn{1}{c|}{$\begin{array}{c}\text { Structural } \\
\text { model }\end{array}$} \\
\hline $\boldsymbol{X}^{2}(\mathbf{d f})$ & - & 267.801 & 264.712 \\
\hline $\boldsymbol{X}^{2} /(\mathbf{d f})$ & $<3$ & 2.16 & 2.13 \\
\hline $\mathbf{P}$ & $>0.05$ & 0.06 & 0.07 \\
\hline Degree of freedom & - & 161 & 159 \\
\hline Goodness-of-fit index (GFI) & $>0.90$ & 0.919 & 0.912 \\
\hline Adjusted goodness-of-fit index (AGFI) & $>0.80$ & 0.840 & 0.832 \\
\hline $\begin{array}{l}\text { Root mean square error of } \\
\text { approximation (RMSEA) }\end{array}$ & $<0.06$ & 0.053 & 0.051 \\
\hline Normed fit index (NFI) & $>0.80$ & 0.800 & 0.822 \\
\hline Comparative fit index (CFI) & $>0.90$ & 0.905 & 0.914 \\
\hline
\end{tabular}


Table 6. Hypothesis testing in the structural model

\begin{tabular}{|c|c|c|c|}
\hline Hypothesis & Relationship & Standardized coefficient $(\beta)$ & Results \\
\hline $\mathrm{H} 1$ & $\mathrm{PEOU} \rightarrow \mathrm{US}$ & $0.328^{* *}$ & Supported \\
\hline $\mathrm{H} 2$ & $\mathrm{PU} \rightarrow \mathrm{US}$ & $0.442 *$ & Supported \\
\hline $\mathrm{H} 3$ & $\mathrm{SI} \rightarrow \mathrm{US}$ & $0.433^{\mathrm{ns}}$ & Not supported \\
\hline $\mathrm{H} 4$ & $\mathrm{SI} \rightarrow \mathrm{PU}$ & $0.610^{* * *}$ & Supported \\
\hline H5 & $\mathrm{CS} \rightarrow \mathrm{US}$ & $0.351^{* * *}$ & Supported \\
\hline H6 & $\mathrm{CS} \rightarrow \mathrm{PU}$ & $0.460^{* * *}$ & Supported \\
\hline $\mathrm{H} 7$ & $\mathrm{PP} \rightarrow \mathrm{US}$ & $0.325^{*}$ & Supported \\
\hline H8 & $\mathrm{PS} \rightarrow \mathrm{US}$ & $0.496^{* * *}$ & Supported \\
\hline H9 & $\mathrm{PS} \rightarrow \mathrm{PP}$ & $0.765^{* * *}$ & Supported \\
\hline H10 & $\mathrm{AW} \rightarrow \mathrm{US}$ & $0.765^{* * *}$ & Supported \\
\hline H11 & $\mathrm{AD} \rightarrow \mathrm{US}$ & $0.341^{\text {ns }}$ & Not supported \\
\hline $\mathrm{H} 12$ & $\mathrm{AD} \rightarrow \mathrm{AW}$ & $0.556^{* *}$ & Supported \\
\hline H13 & $\mathrm{AD} \rightarrow \mathrm{PEOU}$ & $0.269^{\mathrm{ns}}$ & Not supported \\
\hline H14 & $\mathrm{AD} \rightarrow \mathrm{PU}$ & $0.426^{\mathrm{ns}}$ & Not supported \\
\hline H15 & $\mathrm{AC} \rightarrow \mathrm{US}$ & $0.385^{\mathrm{ns}}$ & Not supported \\
\hline H16 & $\mathrm{AC} \rightarrow \mathrm{PU}$ & $0.374 * *$ & Supported \\
\hline
\end{tabular}

( $\beta=0.442, p<0.05)$, Cost Saving $(\beta=0.351, p<0.001)$, Perceived Security $(\beta=0.496, p<0.001)$, and Perceived Privacy $(\beta=0.325, p<0.05)$. Therefore, Hypotheses $1,2,5,7,8$ and 10 were supported. In contrast, no significant relationship could be found between Usage and Advertising, Accuracy of information, and Social Influence; therefore, Hypotheses 3, 11 and 15 were rejected. Advertising was found to have a direct impact on citizens' awareness $(\beta=0.556, p<0.001)$, but no significant influence on Perceived Ease of Use or Perceived Usefulness. Therefore, Hypothesis 12 was validated, but Hypotheses 13 and 14 were rejected. Cost Saving $(\beta=0.460, p<0.001)$, Accuracy $(\beta=0.374$, $p<0.001)$ and Social Influence $(\beta=0.610, p<0.001)$ were all significantly associated with Perceived Usefulness; and Perceived Security was found to impact on Perceived privacy $(\beta=0.765, p<0.001)$. These results validated Hypotheses 4, 6, 9 and 16 respectively. Figure 2 presents a summary of these results, allowing direct comparison with the original research model (Figure 1).

\subsubsection{Demographic Factors}

Five demographic factors were included in the survey (Table 2). These were tested against the ten factors in the model (Figure 2) to identify significant correlations (using Spearman Correlation Coefficient). Since this resulted in 50 tests, the threshold for significance was set at $p=0.01$ instead of $p=0.05$ (i.e., each test had a 1 in 100 chance of falsely showing as significant, as opposed to the usual level of 1 in 20).

Results suggest that, overall demographic factors had little influence. Age was the most important demographic factor (Table 7), with older respondents proving more likely to be aware of the scheme, and less susceptible to Social Influence. Income was also significantly correlated to awareness, with more highly paid respondents tending to show greater awareness. Commuters and residents were significantly less likely to be influenced by accessibility than visitors to London, possibly because 


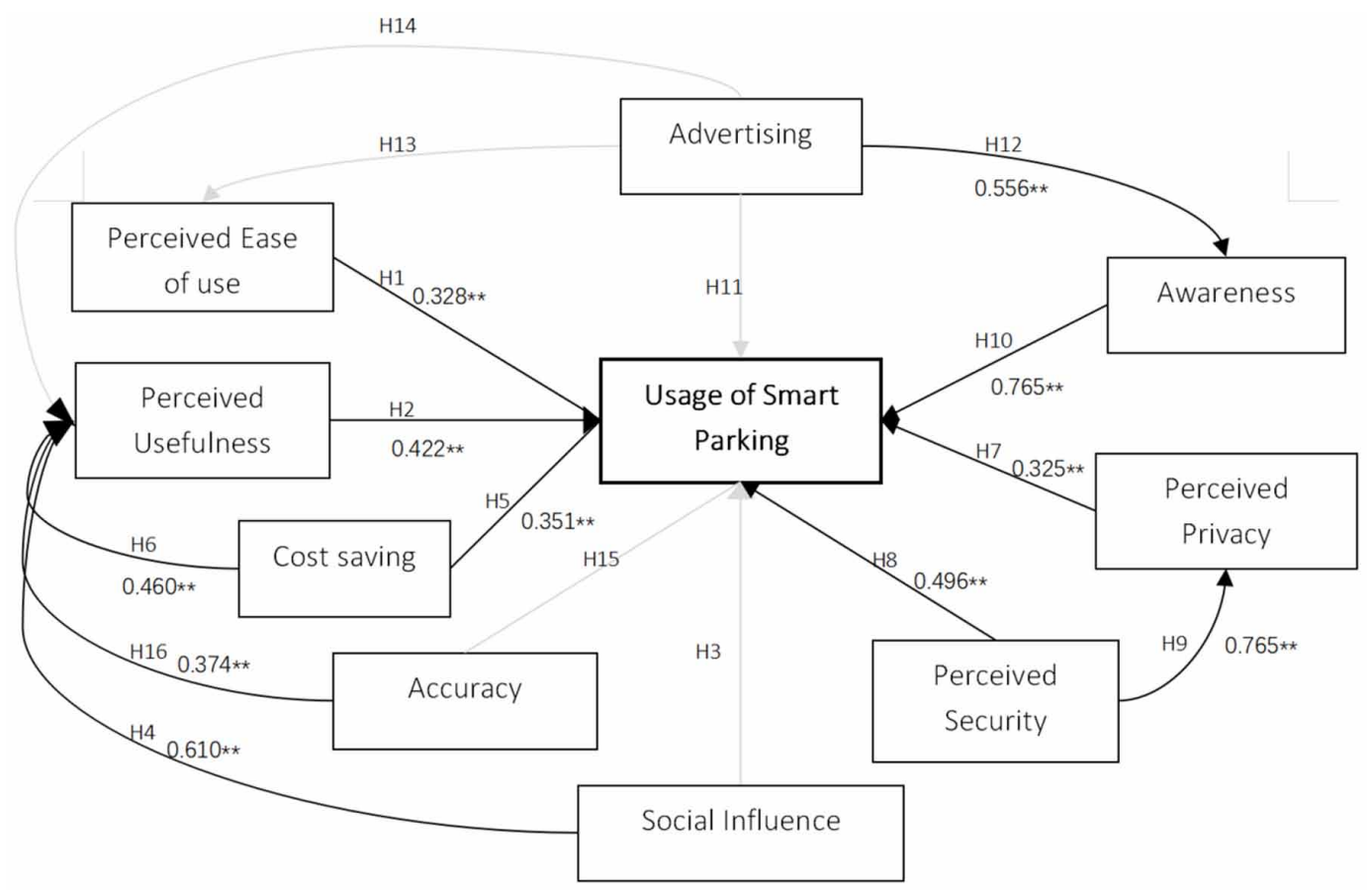

Table 7. Significant demographic Spearman correlations

\begin{tabular}{|l|l|l|l|}
\hline & \multicolumn{1}{|c|}{ Age } & \multicolumn{1}{c|}{ Income } & \multicolumn{1}{c|}{ Working/living or travelling? } \\
\hline Awareness & $0.298^{* * *}$ & $0.297^{* *}$ & \\
\hline Accessibility & & & $-0.232^{* *}$ \\
\hline Social influence & $-0.210^{* *}$ & & \\
\hline
\end{tabular}

they had a more comprehensive knowledge of local parking schemes allowing them to adopt a wider range of criteria when choosing where to leave their vehicles.

\section{DISCUSSION}

\subsection{Addressing the Research Questions}

The questions posed in section 3 were explored using the SEM presented in Figure 1, which is built around 16 hypotheses. Tests of the hypotheses confirm that peoples' perceptions (PEoU and PU) did influence the use of the Westminster Smart Parking scheme. Two factors (Cost Saving and Social Influence) were initially thought to motivate people to use the scheme. Cost Saving had a direct influence on usage; however, Social Influence did not. This aligns with findings from existing research. For example, Venkatesh et al. (2003) found that in a voluntary setting, the effect of Social Influence was indirect and influenced peoples' perceptions about the technology. This was the case in this study, where H4 (Perceived Usefulness is affected by Social Influence) proved to be significant. 
Perceived Security and Perceived Privacy influenced the use of the scheme, but the most influential factor in the adoption of London's Smart Parking scheme proved to be Awareness. As reported elsewhere (Peng et al, 2017), despite substantial efforts to advertise the Smart Parking scheme, nearly three quarters (156 out of 212) of the respondents had seldom heard of it. Advertising may have had some impact on overall awareness (Figure 2, H12), but it seems to have had little direct influence on usage of the parking scheme, or on perceptions of the scheme's usefulness and usability (Figure 2, H11, H13, H14) reinforcing the point made by Peng et al (2017) that advertising needs to be not only widespread, but appropriate. The positive correlation between age and Awareness (Table 7) suggests that the advertisers may have focused on traditional channels, and neglected to make full use of the potential of newer means of raising awareness, such as social media, to attract the attention of the younger generation.

In summary, the model presented in Figure 2, like many others relating to the use of Smart Parking, found Perceived Ease of Use, Perceived Usefulness, Perceived Security, Perceived Privacy, and Cost Saving to be significantly associated with Usage of Smart Parking. However, lack of awareness means that interpretation of the model must, of necessity, be tentative. It is highly likely that the impact of some factors is underestimated since responses to the questionnaire were dominated by the views of people less familiar with the scheme.

\subsection{Theoretical Implications}

The study has a number of important theoretical implications. This is one of the few studies to have investigated technology usage and user behaviour in the context of Smart Cities in general, and Smart Parking in particular. It reinforces findings relating to earlier studies surrounding the adoption of new smart technologies by confirming the importance of Perceived Ease of Use (e.g., Davis et al., 1989), Perceived Usefulness (e.g., Davis et al, 1989), Perceived Security (e.g., Lin \& Lu, 2015), Perceived Privacy (e.g., Sepasgozar et al, 2019) and Awareness (e.g., Peng et al, 2017). In addition, it provides evidence to support the view that Cost Saving, Accuracy, and Social Influence can shape people's perceptions of the usefulness of smart parking schemes, and so either directly or indirectly affect citizens' willingness to use such technology. Overall, the results of this study provide a theoretical foundation for future research into behaviour associated with smart technologies in a city context.

\subsection{Practical Implications}

The findings of this study provide new insights into key factors affecting the usage of Smart Parking schemes, not just in London but more widely. The evidence gathered suggests that potential users of smart parking could be deterred by the energy and effort required to learn how to use the scheme, as well as by concerns over data privacy and security risks. Designers of Smart Parking apps should, therefore, ensure that the interface is simple and clear and requires minimal effort. However, to ensure data privacy and to reduce risks to security, city governors cannot just reply on technical solutions (Dutta et al, 2013). Rigorous data protection regulations need to be established and clearly enforced, to make sure that citizen data captured through smart apps cannot be misused or accessed by unauthorized parities (Dutta et al, 2013). The study also found that perceptions of the usefulness of Smart Parking schemes is dependent on potential cost savings, the quality of information provided, and the views of friends and family members. These factors should thus be fully considered in any marketing and promotion strategies aimed at attracting the interest of citizens, raising their awareness and increasing their use of the scheme. In sum, city governors, app developers, and service providers in London and elsewhere should consider the findings presented to improve the quality and usage of smart parking schemes and to realise their potential benefits.

\subsection{Limitations and Future Studies}

While this study contributes to both theory and practice we also recognize that it has limitations, especially with respect to the survey sample. Since the study only involved residents of, and visitors 
to, London, who volunteered to participate the generalizability of its findings is reduced. In addition, this research focuses specifically on Smart Parking, which is just one of a range of smart schemes and services deployed in modern cities. However, the factors identified and hypotheses confirmed may be relevant to other smart city initiatives (e.g., cost saving and information accuracy are arguably also relevant to smart bus schemes), though this needs further investigation and testing.

Given these limitations and the current scarcity of studies investigating usage and behaviour in the smart city context, further research in this area is strongly recommended. Future research can draw on the research model and findings of this study, and seek to test the validity of the model by assessing its relevance to other cities and other smart city schemes.

\section{CONCLUSION}

London is a major tourist destination, so demand for parking is high across the city. However, because Westminster is the location of many prominent employers (primarily, the UK government) much of this demand comes from commuters rather than leisure travellers. This is significant, because commuters have far less flexibility than tourists in their choice of where and when to park.

Westminster City Council invested approximately $£ 890,000$ in the Smart Parking scheme, demonstrating a clear commitment to the idea of using IoT technologies to improve transport in the Borough.

These two observations make the findings of this study particularly surprising. Because commuters working in Westminster are restricted in their choice of parking, they would have been interested in developments designed to make parking easier and more flexible. Since Westminster City Council have invested a significant proportion of its income on a scheme designed to improve parking, it would have been keen for the Smart Parking scheme to be well-used. However, despite the fact that the scheme's provider had a clear motivation for publicising the scheme, and the target users had a clear motivation for finding out about it, awareness (or, more accurately, lack of awareness) proved to be the most influential factor in the adoption of London's Smart Parking scheme.

This disconnect between providers of a technological solution and potential beneficiaries of the solution, is another example of the way in which social factors can impact on the implementation of technology; and it reinforces the need for researchers to explore the full range of socio-technical issues that may affect smart city development.

\section{ACKNOWLEDGMENT}

This research was supported by two grants respectively funded by the National Natural Science Foundation of China (No.: 71974215) and the Natural Science Foundation of Guangdong (No.: 2018A030313706). 


\section{REFERENCES}

Ajzen, I. (1991). The theory of planned behavior. Organizational Behavior and Human Decision Processes, 50(2), 179-211. doi:10.1016/0749-5978(91)90020-T

Allwinkle, S., \& Cruickshank, P. (2011). Creating smart-er cities: An overview. Journal of Urban Technology, 18(2), 1-16. doi:10.1080/10630732.2011.601103

Bagozzi, R. P., \& Yi, Y. (1988). On the evaluation of structural equation models. Journal of the Academy of Marketing Science, 16(2), 74-94. doi:10.1007/BF02723327

Belanche-Gracia, D., Casaló-Ariño, L. V., \& Pérez-Rueda, A. (2015). Determinants of multi-service smartcard success for smart cities development: A study based on citizens' privacy and security perceptions. Government Information Quarterly, 32(2), 154-163. doi:10.1016/j.giq.2014.12.004

Bryman, A. (2004). Social research methods (2nd ed.). Oxford University Press.

Cardone, G., Cirri, A., Corradi, A., \& Foschini, L. (2014). The participact mobile crowd sensing living lab: The testbed for smart cities. IEEE Communications Magazine, 52(10), 78-85. doi:10.1109/MCOM.2014.6917406

Chourabi, H. (2012). Understanding smart cities: an integrative framework. Proceedings of the 45th Hawaii International Conference on System Sciences. doi:10.1109/HICSS.2012.615

Christidis, P., \& Rivas, J. N. I. (2012). Measuring road congestion. Institute for Prospective Technological Studies (IPTS), European Commission Joint Research Centre. Retrieved from http://ipts. jrc. ec. euro pa. eu/ publications/pub. cfm

Collins, N. (2014). Parking sensors to end drivers' parking nightmare in Westminster. The Telegraph. https:// www.telegraph.co.uk/news/uknews/road-and-rail-transport/11193768/Parking-sensors-to-end-drivers-parkingnightmare-in-Westminster.html

Curtis, S. (2014). Smart parking app begins rollout in London's West End. The Telegraph. https://www.telegraph. co.uk/technology/news/10573651/Smart-parking-app-begins-rollout-in-Londons-West-End.html

Davis, F., Bagozzi, R. P., \& Warshaw, P. R. (1989). User acceptance of computer technology: A comparison of two theoretical models. Management Science, 35(8), 982-1002. doi:10.1287/mnsc.35.8.982

Davis, F. B. (1964). Educational Measurements and their Interpretation. Wadsworth.

Davis, F. D. (1985). A Technology Acceptance Model for Empirically Testing New End-User Information Systems: Theory and Results (Doctoral Dissertation). MIT Sloan School of Management, Cambridge, MA.

Dehghani, M., Kim, K. J., \& Dangelico, R. M. (2018). Will smartwatches last? Factors contributing to intention to keep using smart wearable technology. Telematics and Informatics, 35(2), 480-490. doi:10.1016/j. tele.2018.01.007

Department for Transport. (2018). Licenced vehicles - numbers, borough. Open Dataset provided by local authority. https://data.london.gov.uk/dataset/licensed-vehicles-numbers-borough

Dutta, A., Peng, G. C., \& Choudhary, A. (2013). Risks in enterprise cloud computing: The perspective of IT experts. Journal of Computer Information Systems, 53(4), 39-48. doi:10.1080/08874417.2013.11645649

Edquist, J., Rudin-Brown, C. M., \& Lenné, M. G. (2012). The effects of on-street parking and road environment visual complexity on travel speed and reaction time. Accident; Analysis and Prevention, 45, 759-765. doi:10.1016/j.aap.2011.10.001 PMID:22269567

Fabusuyi, T., Hampshire, R., \& Hill, V. (2013). Evaluation of a smart parking system. Transportation Research Record: Journal of the Transportation Research Board, 2359(1), 10-16. doi:10.3141/2359-02

Fornell, C., \& Larcker, D. F. (1981). Evaluating structural equation models with unobservable variables and measurement error. JMR, Journal of Marketing Research, 18(1), 39-50. doi:10.1177/002224378101800104

Geng, Y., \& Cassandras, C. G. (2012). A new "Smart Parking" System Infrastructure and Implementation. Procedia: Social and Behavioral Sciences, 54, 1278-1287. doi:10.1016/j.sbspro.2012.09.842 
Gope, P., \& Hwang, T. (2015). Untraceable sensor movement in distributed IoT infrastructure. IEEE Sensors Journal, 15(9), 5340-5348. doi:10.1109/JSEN.2015.2441113

Greater London Authority. (n.d.). Land Area and Population Density. Open Dataset provided by local authority. https://data.london.gov.uk/dataset/land-area-and-population-density-ward-and-borough

Hair, J. F., Anderson, R. E., Tatham, R. L., \& Black, W. C. (1998). Multivariate Data Analysis. Prentice Hall.

Hashem, I. A. T., Chang, V., Anuar, N. B., Adewole, K., Yaqoob, I., Gani, A., \& Chiroma, H. (2016). The role of big data in smart city. International Journal of Information Management, 36(5), 748-758. doi:10.1016/j. ijinfomgt.2016.05.002

Huy, L. V., Rowe, F., Truex, D., \& Huynh, M. Q. (2012). An empirical study of determinants of e-Commerce adoption in SMEs in Vietnam: An economy in transition. Journal of Global Information Management, 20(3), 23-54. Advance online publication. doi:10.4018/jgim.2012070102

Ilhan, A., Fietkiewicz, K. J., \& Stock, W. G. (2017, July). Do Car Drivers Really Need Mobile Parking Payment? In International Conference of Design, User Experience, and Usability (pp. 241-254). Springer. doi:10.1007/9783-319-58637-3_19

Kaplan, R. W., \& Saccuzzo, D. P. (2008). Psychological Testing: Principles, Applications, and Issues (7th ed.). Brooks/Cole Monterey.

Khan, I. U., Hameed, Z., \& Khan, S. U. (2017). Understanding online banking adoption in a developing country: UTAUT2 with cultural moderators. Journal of Global Information Management, 25(1), 43-65. Advance online publication. doi:10.4018/JGIM.2017010103

Kianpisheh, A., Mustaffa, N., See, J. M. Y., \& Keikhosrokiani, P. (2011, November). User behavioral intention toward using smart parking system. In International Conference on Informatics Engineering and Information Science (pp. 732-743). Springer. doi:10.1007/978-3-642-25453-6_61

Lan, K. C., \& Shih, W. Y. (2014). An intelligent driver location system for smart parking. Expert Systems with Applications, 41(5), 2443-2456. doi:10.1016/j.eswa.2013.09.044

Lewis-Beck, M. S. (1994). Factor Analysis and Related Techniques (5th ed.). Sage Publication.

Lin, K. Y., \& Lu, H. P. (2015). Predicting mobile social network acceptance based on mobile value and social influence. Internet Research, 25(1), 107-130. doi:10.1108/IntR-01-2014-0018

Long, J. S. (1983). Confirmatory factor analysis: A preface to LISREL (Vol. 33). Sage Publications. doi: $10.4135 / 9781412983778$

Maria, G., Baccaglini, E., Brevi, D., Gavelli, M., \& Scopigno, R. (2016). A drone-based image processing system for car detection in a smart transport infrastructure. In 2016 18th Mediterranean Electrotechnical Conference (MELECON) (pp. 1-5). IEEE. doi:10.1109/MELCON.2016.7495454

Minoli, D., Sohraby, K., \& Occhiogrosso, B. (2017). IoT considerations, requirements, and architectures for smart buildings-energy optimization and next-generation building management systems. IEEE Internet of Things Journal, 4(1), 269-283. doi:10.1109/JIOT.2017.2647881

Mojtahed, R., Nunes, J. M. B., Martins, J. T., \& Peng, G. C. (2014). Equipping the constructivist researcher: The combined use of semi-structured interviews and decision-making maps. Electronic Journal of Business Research Methods, 12(2), 87-95.

Nam, T., \& Pardo, T. A. (2011). Conceptualizing smart city with dimensions of technology, people, and institutions. Proceedings of the 12th Annual International Conference on Digital Government Research. doi:10.1145/2037556.2037602

Neirotti, P., De Marco, A., Cagliano, A. C., Mangano, G., \& Scorrano, F. (2014). Current trends in Smart City initiatives: Some stylised facts. Cities (London, England), 38, 25-36. doi:10.1016/j.cities.2013.12.010

Nunnally, J. C. (1978). Psychometric Theory (2nd ed.). McGraw-Hill Book Co.

Nunnally, J. C., \& Bernstein, I. H. (1967). Psychometric Theory (3rd ed.). McGraw-Hill. 
Oghuma, A. P., Libaque-Saenz, C. F., Wong, S. F., \& Chang, Y. (2016). An expectation-confirmation model of continuance intention to use mobile instant messaging. Telematics and Informatics, 33(1), 34-47. doi:10.1016/j. tele.2015.05.006

Peng, G., Nunes, M., \& Zheng, L. (2017). Impacts of low citizen awareness and usage in smart city services: The case of London's smart parking system. Information Systems and e-Business Management, 15(4), 845-876. doi:10.1007/s10257-016-0333-8

Peng, G. C., \& Annansingh, F. (2013). Experiences in applying mixed-methods approach in information systems research. In P. Isaias \& M. B. Nunes (Eds.), Information systems research and exploring social artifacts:approaches and methodologies (pp. 266-293). IGI Global. doi:10.4018/978-1-4666-2491-7.ch014

Pereira, G. V., Macadar, M. A., Luciano, E. M., \& Testa, M. G. (2017b). Delivering public value through open government data initiatives in a Smart City context. Information Systems Frontiers, 19(2), 213-229. doi:10.1007/ s10796-016-9673-7

Qiu, T., Liu, J., Si, W., Han, M., Ning, H., \& Atiquzzaman, M. (2017). A data-driven robustness algorithm for the Internet of things in smart cities. IEEE Communications Magazine, 55(12), 18-23. doi:10.1109/ MCOM.2017.1700247

Rodier, C. J., \& Shaheen, S. A. (2010). Transit-based smart parking: An evaluation of the San Francisco bay area field test. Transportation Research Part C, Emerging Technologies, 18(2), 225-233. doi:10.1016/j.trc.2009.07.002

Rogers, E. (1995). Diffusion of Innovations. United States. Free Press.

Rouibah, K., \& Hamdym, H. (2009). Factors affecting information communication technologies usage and satisfaction: Perspective from instant messaging in Kuwait. Journal of Global Information Management, 17(2), 1-29. Advance online publication. doi:10.4018/jgim.2009040101

Scott, J. (1994). The measurement of information systems effectiveness: evaluating a measuring instrument. Proceedings of the Fifteenth International Conference on Information Systems, 111-128.

Sepasgozar, S. M., Hawken, S., Sargolzaei, S., \& Foroozanfa, M. (2019). Implementing citizen centric technology in developing smart cities: A model for predicting the acceptance of urban technologies. Technological Forecasting and Social Change, 142, 105-116. doi:10.1016/j.techfore.2018.09.012

Shin, J., Park, Y., \& Lee, D. (2018). Who will be smart home users? An analysis of adoption and diffusion of smart homes. Technological Forecasting and Social Change, 134(6), 246-253. doi:10.1016/j.techfore.2018.06.029

Talukder, M. S., Chiong, R., Corbitt, B., \& Bao, Y. (2020). Critical factors influencing the intention to adopt m-Government services by the elderly. Journal of Global Information Management, 28(4), 74-94. Advance online publication. doi:10.4018/JGIM.2020100105

Telegraph. (2014). Smart parking app begins rollout in London's West End. https://www.telegraph.co.uk/ technology/news/10573651/Smart-parking-app-begins-rollout-in-Londons-West-End.html

Teodorović, D., \& Lučić, P. (2006). Intelligent parking systems. European Journal of Operational Research, 175(3), 1666-1681. doi:10.1016/j.ejor.2005.02.033

Venkatesh, V., Morris, M. G., Davis, G. B., \& Davis, F. D. (2003). User acceptance of information technology: Toward a unified view. Management Information Systems Quarterly, 27(3), 425-478. doi:10.2307/30036540

Venkatesh, V., Thong, J. Y., \& Xu, X. (2016). Unified theory of acceptance and use of technology: A synthesis and the road ahead. Journal of the Association for Information Systems, 17(5), 328-376. doi:10.17705/1jais.00428

Williams, M. D., Yogesh, N. P. R., \& Dwivedi, K. (2015). The Unified Theory of Acceptance and Use of Technology (UTAUT): A literature review. Journal of Enterprise Information Management, $28(3), 443-488$. doi:10.1108/JEIM-09-2014-0088

$\mathrm{Xu}$, J., Benbasat, I., \& Cenfetelli, R. T. (2013). Integrating service quality with system and information quality: An empirical test in the e-service context. Management Information Systems Quarterly, 37(3), 777-794. doi:10.25300/MISQ/2013/37.3.05

Yamagata, Y., \& Seya, H. (2013). Simulating a future smart city: An integrated land use-energy model. Applied Energy, 112, 1466-1474. doi:10.1016/j.apenergy.2013.01.061 
Yeh, H. (2017). The effects of successful ICT-based smart city services: From citizens' perspectives. Government Information Quarterly, 34(3), 556-565. doi:10.1016/j.giq.2017.05.001

Zhang, B., Peng, G., Xing, F., Liang, X. \& Gao, Q. (2021). One-Stop Smart Urban Apps and Determinants of their Continuance Usage: An Empirical Investigation Based on CSCM. Journal of Global Information Management, 29(6).

Guochao Peng $(P h D)$ is based at the School of Information Management at Sun Yat-sen University, China. He holds a BSc in Information Management (1st Class Honours) and a PhD in Information Systems (IS), both from the University of Sheffield. Prof Peng has over 70 publications in the IS field, including 1 book, 1 edited conference proceeding, 7 book chapters, 18 high-quality journal articles, and 30 referred full conference papers. He is the co-founder and co-chair of the IADIS International Conference on Information Systems Post-Implementation and Change Management (ISPCM) since 2012. He has also conducted peer review of submissions to more than 15 leading IS journals and international conferences. Guochao Peng is the corresponding author of this paper.

Paul Clough (PhD) works part-time as Professor of Search and Analytics at the Information School, University of Sheffield (http://www.shef.ac.uk/is/staff/clough). During his time in the department, as well as contributing to research and teaching activities, Paul has been head of the Information Retrieval Group, Director of Research, and coordinator of the MSc Data Science programme. Paul conducts research in areas including Al and Data Science, Information Retrieval, Data Analytics and Natural Language Processing. Paul is also Head of Data Science for Peak Indicators (https://Www.peakindicators.com/), a UK-based Business Intelligence and Analytics company, where he is helping to develop data products and services, produce educational resources and grow the data science capability within Peak Indicators. Prior to working at the University of Sheffield and Peak Indicators, Paul worked in R\&D for British Telecommunications Plc at Adastral Park (UK). Paul is Fellow of the Higher Education Academy and Member of the British Computer Society. Andrew Madden has been a researcher for many years. He has worked in the iSchools of Sheffield University, UK and of Sun-yat Sen University, China, where he has investigated various aspects of information management, ranging from library governance to big data. He is an expert on information behaviour, and has a particular interest in the impact of new technologies on education.

Fei Xing is a PhD student in Information Science in the School of Information Management at Sun Yat-Sen University, China. He earned his MSc in Information Systems at the University of Sheffield, UK. He has published a number of papers in both top journals and international conferences in smart manufacturing, smart cities and smart healthcare.

Bingqian Zhang is a PhD student in Information Science in the School of Information Management at Sun Yat-Sen University, China. Her research focused on the fields of smart city, smart health, and user behaviour. She has been a key participant of a number of national and industrial grants, and has published a number of papers in both journals and international conferences. 